\title{
Smart Shoppers' Purchasing Experiences: Functions of Product Type, Gender, and Generation
}

\author{
Kelly Green Atkins ${ }^{1} \&$ Sae-Young Jessica Hyun ${ }^{2}$ \\ ${ }^{1}$ Department of Management and Marketing, East Tennessee State University, Johnson City, TN, USA \\ ${ }^{2}$ Honors Student, Farragut High School, Knoxville, TN, USA \\ Correspondence: Kelly Green Atkins, Department of Management and Marketing, East Tennessee State \\ University, Johnson City, TN 37614, USA. United States. Tel: 1-423-439-5384. E-mail: atkins@etsu.edu
}

\author{
Received: January 19, 2016 Accepted: February 14, $2016 \quad$ Online Published: March 25, 2016 \\ doi:10.5539/ijms.v8n2p1 URL: http://dx.doi.org/10.5539/ijms.v8n2p1
}

\begin{abstract}
Today's consumers want to feel smart while shopping by minimizing the costs associated with shopping trips (e.g., time, effort, or money) and maximizing the benefits (e.g., convenience, ease, or finding the right product). This study examined whether smart purchasing experiences (i.e., effort and time saving, money saving, and making the right purchase) differ by product type, gender, and generation, after adjusting to the same levels of search and planning that were made before purchasing. Using 1474 respondents drawn by an online consumer panel, a series of ANCOVAs along with MANCOVA revealed that members of different genders and generational cohorts, when purchasing different product types, demonstrate distinct smart shopping purchase experiences in terms of saving time/effort, saving money, and making the right purchase. Specific suggestions are made for marketers to target each consumer and product group.
\end{abstract}

Keywords: effort saving, money saving, right purchase, smart purchasing experience, smart shopper, time saving

\section{Introduction}

To attract consumers, retailers must create unique positioning strategies that stay ahead of today's changing U.S. marketplace. One area of change is socioeconomics - the unique combination of social and economic factors that influence consumer behavior. Socioeconomic changes such as the ubiquitous presence of time poverty in dual-income families and single-parent households are impacting consumer shopping patterns (Crutsinger, 2006; Kim, Lee, \& Park, 2014). To these consumers, shopping can be a chore rather than a recreational activity (Kim, Sullivan, \& Forney, 2007). The recent economic recession in the United States has also influenced shopping patterns by causing consumers to consider trip consolidation (Cardinali \& Bellini, 2014). As a result of these and other factors, consumers are shopping more infrequently, visiting fewer stores per trip, and spending less per purchase (Kim, Lee, \& Park, 2014). It follows that U.S. consumers desire convenient locations, seemingly effortless shopping, and low prices to assist them in finding the right product(s).

Recent technological advances in mobile shopping through location-based services are blurring the lines between brick-and-mortar and Internet retailing (Brynjolfsson, Hu, \& Rahman, 2013). For example, online mobile services are enabling consumers to search for product and service availability in local stores before traveling to the store to make a purchase, thus meeting the need for convenience of consumers ("The future of retail," 2013). In fact, educational attainment and the advancement of technology have allowed consumers to become more knowledgeable and aware of their shopping options. Indeed, retailers and marketers must keep abreast of changes in consumer wants and needs in order to create satisfied shopping experiences.

In sum, today's busy consumers want to minimize the costs associated with shopping trips (e.g., time or money) and maximize the benefits (e.g., convenience or ease). This epitomizes today's "smart shopper;" however, there is a dearth of research on how this smart shopper purchasing experience differs according to product types and consumer groups. Recently, Atkins \& Kim (2012) developed a smart shopping scale consisting of three factors: effort/time saving, money saving, and right purchase. The present study will explore whether these smart shopping factors are distinctive among different consumer and product groups. Further, the level of distinct smart purchasing experiences may depend upon how much preparation went into the purchase. For example, some consumers may spend a significant amount of time searching where to shop and how much they are willing to pay 
for what they want. These consumers may not experience the feelings of smart shopping as compared to those consumers who did not spend search time before purchasing. As a result, this study will examine whether smart purchasing experiences differ by product type, gender, and generation, after controlling for the amount of search and planning that were made before purchasing.

\section{Research Background}

\subsection{Smart Shoppers' Purchasing Experiences}

The term smart shopping can be frequently observed on television, in magazines, and on the Internet. Such discussions of smart shopping include consumer participation in information gathering, planning, comparison shopping, or shopping enjoyment (Wallner \& Matisic, 2005). In 1997, Mano \& Elliott defined smart shopping as "a tendency for consumers to invest considerable time and effort in seeking and utilizing promotion-related information to achieve price savings" (p. 504). The literature contains additional smart shopping research studies focused on saving money, time, and effort (Garretson \& Burton, 2003; Schindler, 1998; Shimp \& Kavas, 1984). On the other hand, other researchers report that consumers want additional benefits (beyond saving money, time and effort) from the shopping experience (Kim, Sullivan, \& Forney, 2007). Such consumers, wanting to increase the benefits received from the shopping experience while desiring to save time, money and effort, have been identified as smart shoppers (Atkins \& Kim, 2012; Mano \& Elliott, 1997; Schindler, 1998). Though understanding smart shoppers and the meaning of the term "smart shopping" is important for retailers, marketers, and researchers, the literature lacks studies that examine smart shopper purchasing experiences. Furthermore, smart purchasing experiences may differ based on product types and consumer groups, which is the focus of this study.

\subsection{Product Type}

In 1923, Copeland classified products into three classes: convenience goods, shopping goods and specialty goods. Other researchers have redefined and extended this classification (Bucklin, 1963; Murphy \& Enis, 1986). Convenience goods are products for which consumers typically try to reduce time and energy costs (Murphy \& Enis, 1986). The grocery category is traditionally classified as convenience goods that involve minimal purchasing effort or time and little consumer preference (Bucklin, 1963; Copeland, 1923; Holton, 1958). Clothing is an example of shopping goods for which the consumer spends a substantial amount of time comparing and selecting products based upon appropriateness, style, quality and price. Products for which consumers are willing to expend time, energy, and money are called specialty goods (Murphy \& Enis, 1986). These goods, such as small electronics, are depicted by infrequent purchases, a significant purchasing effort, and brand loyalty because the consumer will not accept substitutes (Bucklin, 1963).

In 1986, Murphy \& Enis classified products in terms of effort (the amount of time, money, and energy the consumer is willing to spend on a product) and risk (assessment of the consequences of making a purchasing mistake). According to this classification, convenience goods require low levels of effort and risk. Shopping goods require a higher level of effort and risk than convenience goods. Further, Murphy \& Enis (1986) reported that specialty goods require a significant increase in effort and risk in making the purchase.

Considering the description of smart shopping provided by Atkins \& Kim (2012) and Mano \& Elliott (1997), product type is likely to influence consumers' perceptions of smart shopping because differing product types require differing levels of time, money, effort, or risk. In this study, three product types were used to examine different experiences associated with smart shopping (e.g., clothing for shopping goods, small electronics for specialty goods, and groceries for convenience goods).

\subsection{Gender}

Demographic variables are commonly used to understand consumers because they form relatively homogeneous groups based on characteristics such as gender and age. The literature reveals distinct gender differences in consumer shopping behavior. For example, Slama \& Tashchian (1985) found that women typically have higher levels of purchasing involvement than men. Bakewell \& Mitchell (2006) argued that shopping has been traditionally viewed as a female activity because women have been the primary agents for buying clothing and household goods and thus more involved in shopping than men. However, a more recent study found that 35-50\% of men are household shoppers for health, pet, packaged goods, and clothing (Neff, 2011). Such changes may be due to increasing numbers of working women and changing gender roles.

Previous studies suggest that males make purchasing decisions differently from females (Bakewell \& Mitchell, 2006; Cleveland, Babin, Laroche, Ward, \& Bergeron, 2003). A crucial difference between male and female shopping is the length of shopping trip; men make purchases more quickly (Dennis \& McCall, 2005) and spend less time per shopping trip than women (Bakewell \& Mitchell, 2006; Hu \& Jasper, 2004). Men want to get in 
and out of a store whereas women want a shopping experience (Men buy, women shop, 2007). Another distinctive gender difference is the amount of shopping enjoyment; women typically enjoy the shopping experience more than men (Cleveland et al., 2003; Hu \& Jasper, 2004; Van Slyke, Comunale, \& Belanger, 2002). These differences support the findings that men are characteristically functional, impulsive shoppers while women are typically hedonic, organized shoppers (Hu \& Jasper, 2004; Men buy, women shop, 2007; Wiedmann, Walsh, \& Mitchell, 2001). Males report being confused by overchoice (Bakewell \& Mitchell, 2004; Cleveland et al., 2003), while females conduct more product search and product/price comparisons (Cleveland et al., 2003; Dennis \& McCall, 2005; Laroche, Saad, Cleveland, \& Browne, 2000). Men often purchase well-known brands to reduce confusion brought on by overchoice and are less focused on promotions than women (Neff, 2011; Wiedmann et al., 2001); however, Brosdahl \& Carpenter (2011) found male participants to be price conscious and brand loyal.

Another difference between men and women is the type of media they use to gather information. A recent study of Millennials found that $89 \%$ of women referred to fashion magazines for information gathering, while only $28 \%$ of males did (Apeagyei, 2011). Similarly, 52\% of women surveyed reported receiving information from television or movies, while only $31 \%$ of men gathered information through these outlets. In contrast, male and female consumers gathered information by word-of-mouth from friends, relatives, or sales associates in comparable numbers ( $42 \%$ males; $41 \%$ females) (Apeagyei, 2011).

In sum, these studies demonstrate that male and female consumers exhibit distinct smart shopping behaviors. Apparently, gender is an important factor that influences smart shoppers' purchasing experiences.

\subsection{Generational Cohort}

Shopper age also affects the shopping behavior of consumers (Miller \& Zikmund, 1975; Urbany, Dickson, \& Kalapurakal, 1996). For example, Urbany et al. (1996) compared older and younger consumers and found that they differed in terms of search behaviors; older consumers searched considerably more than other age groups. Worsley, Wang, \& Hunter (2011) investigated why consumers shopped at specific stores and compared consumers in terms of age and education. They reported that less-educated participants prefer stores that offer price savings, yet as consumer age increased, price savings became less important. The study also found that younger consumers valued convenience more than all other store characteristics (Worsley, Wang \& Hunter, 2011). Young (2011) reported that the secret to success of engaging younger consumers is simply using technology. Typical female teens spend substantial amounts of money on fashionable apparel that boosts their self-confidence (Haytko \& Baker, 2004). In contrast, middle-aged men with little interest in apparel often make purchases swiftly, decisively, and resolutely with less perceived risk (Cleveland et al., 2003).

Generational cohorts refer to segments of consumers who are linked through shared life experiences in a particular period of time (Norum, 2003). These shared experiences and events are thought to create similar values, attitudes, and beliefs among members of the cohort group (Brosdahl \& Carpenter, 2011). According to Reeves \& Oh (2007), Generation Yers (Millennials) were born from 1981 to 1996; Generation Xers were born from 1965 to 1980; Baby Boomers were born from 1946 to 1964; and seniors were born before 1946.

According to a 2009 Nielsen study, Baby Boomers shop more frequently than Gen Xers or Millennials, but Gen Xers and Millennials consistently spend more per trip (Hale, 2010). The Nielsen study also reported that Baby Boomers are more deal prone than other generational cohorts. Similarly, Mushkin (2012) found that though Millennials place a high value on convenience when shopping for food, Baby Boomers employ more cost saving strategies. Additionally, Parment (2013) found that purchase patterns of generational cohorts differ with respect to buyer involvement; Baby Boomers have a higher degree of purchase involvement for groceries and automobiles than Millennials, while purchase involvement for clothing is similar between the two cohorts.

These studies suggest that age/generation is an important variable for comparing consumer purchasing experiences because it influences the ways consumers make purchase decisions. Understanding consumers' smart purchasing behaviors according to generational cohorts will enable marketers to more accurately tailor strategies to meet consumers' needs for smart purchasing experiences.

\subsection{Research Questions}

This study seeks to fill the gap in the literature by investigating smart shoppers' purchasing experiences by product type, by gender, and by generational cohort in terms of effort and time savings, right purchase, and saving money. Given the state of the literature, the researchers raised the following research questions to pursue these objectives:

$R Q 1$. Do smart shopping purchasing experiences differ by product type (shopping goods, convenience, and 
specialty goods) in terms of effort and time saving, right purchase, and money saving?

$R Q 2$. Do smart shopping purchasing experiences differ by gender in terms of effort and time saving, right purchase, and money saving?

RQ3. Do smart shopping purchasing experiences differ by generation in terms of effort and time saving, right purchase, and money saving?

\section{Methodology}

The researchers chose clothing, grocery, and electronics in order to solicit responses for each of the three product types (i.e., shopping goods, convenience goods, and specialty goods). Each product effectively represents the associated product classification (Murphy \& Enis, 1986) and are purchased frequently by consumers.

\subsection{Sample}

The sample, consisting of consumers, age 18 or older, who had purchased clothing, grocery, or electronics in-store in the last three months, was drawn from a pre-recruited consumer panel through an online survey agent. At the beginning of the survey, participants were asked to recall their most recent in-store shopping trip for clothing (shopping goods), grocery (convenience goods) or electronics (specialty goods) when they made what they would consider a smart purchase. After selecting the type of product they purchased, participants answered the questions regarding smart shopping purchasing in reference to the selected product type. Additional questions regarding pre-purchasing activities (i.e., search and planning) and demographic information were included.

Out of 2231 people who accessed the survey link, 1570 participants completed the online survey. After deleting non-usable surveys, 1474 surveys (488 clothing, 751 grocery, and 235 electronics) were utilized. The age categories were fairly evenly distributed with a mean age of 46 years. With respect to ethnicity, $83.7 \%$ of the participants were Caucasian. Almost half of the participants were married (49.2\%) and almost 48 percent had a Bachelor's degree or higher. The sample was fairly equally divided between males (43\%) and females (57\%).

\subsection{Measures and Analyses}

This study was designed to assess the effects of gender, product type, and generation on the three smart shopping purchase factors after controlling the level of pre-purchase activities (i.e., search and planning). As mentioned previously, pre-purchase shopping activities may influence consumer feelings about smart shopping during their actual purchase. For example, the way shoppers perceive saving effort and time during shopping may be impacted by the amount of time spent searching and planning in the pre-purchase stage. Therefore, the researchers employed a three-way multivariate analysis of covariance (MANCOVA) and analyses of covariance (ANCOVAs) with covariates of search and planning. The three independent variables investigated were gender, product type (clothing as shopping goods, grocery as convenience goods, and electronics as specialty goods; Murphy \& Enis, 1986), and generation (Gen Y, Gen X, Baby Boomer, and Senior; Reeves \& Oh, 2007). The three dependent variables ("effort and time savings," "right purchase," and "money saving") were derived from Atkins \& Kim (2012). The two covariates, "planning" and "searching," were adapted from Atkins (2008).

The overall structure of these five factors was validated via Confirmatory Factor Analysis (CFA). The model fits were examined with Chi-square $\left(x^{2}\right)$, degrees of freedom $(d f)$, comparative fit index $(\mathrm{CFI})$, non-normed fit index (NNFI), and root mean square error of approximation (RMSEA) (Hair, Black, Babin, \& Anderson, 2009). Overall, the measurement items were found to be reliable $(>.70)$ and model fits for each product type were satisfactory according to recommendations by Hair et al. (2009). Table 1 illustrates measurement items, factor loadings, construct reliabilities, and model fit indexes for the three product types. In terms of construct validity, convergent validity was satisfied because average variance extracted (AVE) of each factor was above .50 and discriminant validity was satisfied because all correlations across constructs were below the threshold of .85 (Brown, 2006). 
Table 1. Measurement items and reliabilities

\begin{tabular}{|c|c|c|c|}
\hline & Clothing & Grocery & Electronics \\
\hline \multicolumn{4}{|l|}{ Effort/Time Savings } \\
\hline Making this purchase was convenient for me. & 0.773 & 0.784 & 0.783 \\
\hline Making this purchase was not a hassle. & 0.746 & 0.800 & 0.707 \\
\hline I did not spend extra effort on this purchase. & 0.605 & 0.637 & 0.597 \\
\hline In making this purchase, I used my time wisely. & 0.789 & 0.773 & 0.600 \\
\hline I didn't waste time making this purchase. & 0.732 & 0.660 & 0.748 \\
\hline I was able to make this purchase quickly. & 0.657 & 0.726 & 0.588 \\
\hline Construct Reliability & 0.865 & 0.873 & 0.832 \\
\hline \multicolumn{4}{|l|}{ Right Purchase } \\
\hline This purchase was exactly what I was looking for. & 0.674 & 0.649 & 0.692 \\
\hline This purchase perfectly fit my needs. & 0.808 & 0.749 & 0.791 \\
\hline I have gotten everything I expected from this purchase. & 0.782 & 0.769 & 0.847 \\
\hline I got a good quality product from this purchase. & 0.730 & 0.800 & 0.798 \\
\hline This purchase was a very good fit for me. & 0.689 & 0.822 & 0.690 \\
\hline Construct Reliability & 0.914 & 0.910 & 0.925 \\
\hline \multicolumn{4}{|l|}{ Money Savings } \\
\hline I got what I wanted at a price I was willing to pay. & 0.857 & 0.751 & 0.731 \\
\hline I got a lower price on this purchase than normal. & 0.641 & 0.719 & 0.661 \\
\hline I got a reasonable price on this purchase. & 0.870 & 0.809 & 0.827 \\
\hline I got a good deal on this purchase. & 0.802 & 0.855 & 0.886 \\
\hline Construct Reliability & 0.874 & 0.865 & 0.861 \\
\hline \multicolumn{4}{|l|}{ Searching } \\
\hline I conducted research prior to making this purchase. & 0.915 & 0.745 & 0.862 \\
\hline I compared products online & 0.704 & 0.486 & 0.721 \\
\hline I prepared for this purchase by looking through sale ads. & 0.642 & 0.743 & 0.620 \\
\hline Construct Reliability & 0.803 & 0.702 & 0.782 \\
\hline \multicolumn{4}{|l|}{ Planning } \\
\hline I waited until I found the right product. & 0.515 & 0.652 & 0.711 \\
\hline I delayed my purchase until it was at a price I wanted to pay. & 0.791 & 0.787 & 0.669 \\
\hline I waited a while until this product went on sale. & 0.761 & 0.837 & 0.764 \\
\hline Construct Reliability & 0.736 & 0.805 & 0.759 \\
\hline Chi-square & 647.886 & 883.695 & 955.493 \\
\hline$d f$ & 179 & 179 & 179 \\
\hline CFI & 0.961 & 0.959 & 0.934 \\
\hline$N N F I$ & 0.954 & 0.952 & 0.923 \\
\hline RMSEA & 0.070 & 0.073 & 0.093 \\
\hline
\end{tabular}

A multivariate analysis of covariance (MANCOVA) was utilized to protect the analysis from excessive Type I errors in univariate statistical testing (Keselman et al., 1998) and because the three dependent variables were correlated $(\mathrm{r}=.63$ between "effort and time saving" and "right purchase"; $\mathrm{r}=.48$ between "effort and time saving" and "money saving"; and $r=.65$ between "right purchase" and "money saving) (Warne, 2014). The covariates satisfied the assumption of equal slopes since there were no interactions with any of the main effects. Therefore, separate ANCOVA tests examined the effects of gender, product type, and generation on individual response variables. A series of 2 (gender) x 3 (product type) x 4 (generation) analyses of covariance (ANCOVAs) with two covariates were conducted. The researchers examined the main effects and their interaction effects. When the interaction effects existed, the researchers employed a slicing approach to find simple main effects to compare each fixed factor with another fixed factor. All analyses were conducted using PROC GLM in SAS University Edition.

\section{Results}

Table 2 illustrates means $(M)$ and standard deviations $(S D)$ of dependent variables and covariates that resulted from each level of three independent variables. The entire model was assessed with MANCOVA. As illustrated in Table 3, the multivariate result was significant for the three main effects: gender (Wilk's Lambda $=4.34, p<$ 0.01 ), product type (Wilk's Lambda $=5.28, p<0.001$ ), and generation (Wilk's Lambda $=2.69, p<0.01$ ). The interaction result was significant only for gender and product type (Wilk's Lambda $=4.00, p<0.001$ ). Finally, two covariates were also significant: search (Wilk's Lambda $=8.74, p<0.001)$ and planning (Wilk's Lambda $=$ $38.52, p<0.001)$. 
Table 2. Means

\begin{tabular}{|c|c|c|c|c|c|c|c|c|c|c|c|c|c|}
\hline \multirow[b]{2}{*}{ Gender } & \multirow[b]{2}{*}{ Product } & \multirow[b]{2}{*}{ Generation } & \multirow[b]{2}{*}{$\mathrm{N}$} & \multicolumn{2}{|c|}{$\begin{array}{c}\text { Effort_Time } \\
\text { Saving }\end{array}$} & \multicolumn{2}{|c|}{ Right Purchase } & \multicolumn{2}{|c|}{ Money Saving } & \multicolumn{2}{|c|}{ Search } & \multicolumn{2}{|c|}{ Planning } \\
\hline & & & & $M$ & $S D$ & $M$ & $S D$ & $M$ & $S D$ & $M$ & $S D$ & $M$ & $S D$ \\
\hline 1 & 1 & 1 & 26 & 5.09 & 0.76 & 5.25 & 0.70 & 5.17 & 1.01 & 2.49 & 1.65 & 3.83 & 1.43 \\
\hline 1 & 1 & 2 & 57 & 4.91 & 0.69 & 5.13 & 0.80 & 5.38 & 0.80 & 2.66 & 1.21 & 3.70 & 1.26 \\
\hline 1 & 1 & 3 & 60 & 5.04 & 0.67 & 5.39 & 0.55 & 5.52 & 0.66 & 2.35 & 1.07 & 3.77 & 1.38 \\
\hline 1 & 1 & 4 & 22 & 5.27 & 0.43 & 5.38 & 0.52 & 5.64 & 0.39 & 2.32 & 0.83 & 3.73 & 1.40 \\
\hline 1 & 2 & 1 & 35 & 4.61 & 0.86 & 4.67 & 0.89 & 4.91 & 0.89 & 2.72 & 1.26 & 3.27 & 1.10 \\
\hline 1 & 2 & 2 & 101 & 4.97 & 0.89 & 5.15 & 0.85 & 5.30 & 0.89 & 2.76 & 1.11 & 3.37 & 1.49 \\
\hline 1 & 2 & 3 & 118 & 5.07 & 0.69 & 5.21 & 0.69 & 5.36 & 0.77 & 2.65 & 1.14 & 3.27 & 1.50 \\
\hline 1 & 2 & 4 & 64 & 5.13 & 0.47 & 5.21 & 0.53 & 5.43 & 0.56 & 2.85 & 1.05 & 3.62 & 1.52 \\
\hline 1 & 3 & 1 & 36 & 4.75 & 0.86 & 4.99 & 0.88 & 5.13 & 0.81 & 4.31 & 0.93 & 4.19 & 1.28 \\
\hline 1 & 3 & 2 & 52 & 4.78 & 0.74 & 5.24 & 0.61 & 5.15 & 0.88 & 4.09 & 1.11 & 4.10 & 1.20 \\
\hline 1 & 3 & 3 & 47 & 4.89 & 0.77 & 5.16 & 0.70 & 5.19 & 0.73 & 3.89 & 1.16 & 4.01 & 1.29 \\
\hline 1 & 3 & 4 & 21 & 5.10 & 0.50 & 5.32 & 0.45 & 5.31 & 0.63 & 3.51 & 1.12 & 3.76 & 1.56 \\
\hline 2 & 1 & 1 & 53 & 4.82 & 0.96 & 5.30 & 0.67 & 5.61 & 0.54 & 2.65 & 1.30 & 3.74 & 1.38 \\
\hline 2 & 1 & 2 & 104 & 4.93 & 0.69 & 5.26 & 0.54 & 5.59 & 0.62 & 2.35 & 1.13 & 3.56 & 1.42 \\
\hline 2 & 1 & 3 & 124 & 5.01 & 0.64 & 5.25 & 0.61 & 5.56 & 0.55 & 2.43 & 1.16 & 3.88 & 1.45 \\
\hline 2 & 1 & 4 & 52 & 5.02 & 1.02 & 5.32 & 0.84 & 5.61 & 0.79 & 2.37 & 1.14 & 4.05 & 1.38 \\
\hline 2 & 2 & 1 & 70 & 4.96 & 0.67 & 5.24 & 0.65 & 5.24 & 0.81 & 2.60 & 1.31 & 3.03 & 1.45 \\
\hline 2 & 2 & 2 & 121 & 5.02 & 0.77 & 5.24 & 0.65 & 5.36 & 0.67 & 2.76 & 1.16 & 3.35 & 1.45 \\
\hline 2 & 2 & 3 & 162 & 5.20 & 0.70 & 5.31 & 0.56 & 5.41 & 0.59 & 2.66 & 1.13 & 3.52 & 1.45 \\
\hline 2 & 2 & 4 & 92 & 5.26 & 0.58 & 5.33 & 0.63 & 5.34 & 0.74 & 2.49 & 1.04 & 3.55 & 1.46 \\
\hline 2 & 3 & 1 & 17 & 4.96 & 0.64 & 5.31 & 0.46 & 5.12 & 0.63 & 3.91 & 1.49 & 4.02 & 1.58 \\
\hline 2 & 3 & 2 & 24 & 4.90 & 0.93 & 5.22 & 0.87 & 5.27 & 0.96 & 4.55 & 1.23 & 4.47 & 1.37 \\
\hline 2 & 3 & 3 & 20 & 4.97 & 0.71 & 5.43 & 0.46 & 5.35 & 0.85 & 3.94 & 1.30 & 4.20 & 1.38 \\
\hline 2 & 3 & 4 & 19 & 5.23 & 0.65 & 5.66 & 0.45 & 5.49 & 0.68 & 3.82 & 1.53 & 4.16 & 1.66 \\
\hline
\end{tabular}

Note. Gender: 1 = Male, 2 = Female; Product type: 1 = Clothing, 2 = Grocery, 3 = Electronics; Generation: 1 = Generation Y, $2=$ Generation $\mathrm{X}, 3$ = Baby Boomers, 4 = Seniors.

Table 3. Results of MANCOVA and ANCOVA for smart shopping

\begin{tabular}{|c|c|c|c|c|c|c|c|c|c|}
\hline & \multirow[b]{2}{*}{ Gender } & \multirow[b]{2}{*}{ Product } & \multirow[b]{2}{*}{ Generation } & \multirow{2}{*}{$\begin{array}{l}\text { Gender x } \\
\text { Product }\end{array}$} & \multirow{2}{*}{$\begin{array}{l}\text { Gender } \mathrm{x} \\
\text { Generation }\end{array}$} & \multirow{2}{*}{$\begin{array}{l}\text { Product } \mathrm{x} \\
\text { Generation }\end{array}$} & \multirow{2}{*}{$\begin{array}{l}\text { Gender } \mathrm{x} \\
\text { Product } \mathrm{x} \\
\text { Generation }\end{array}$} & \multicolumn{2}{|c|}{ Covariate } \\
\hline & & & & & & & & Search & Planning \\
\hline \multicolumn{10}{|c|}{ Univariate Analysis of Variance } \\
\hline \multicolumn{10}{|l|}{$F$} \\
\hline $\begin{array}{l}\text { Effort_Time } \\
\text { Saving }\end{array}$ & 1.21 & .86 & $6.29^{* * *}$ & $5.12^{* *}$ & .20 & .98 & .91 & 2.97 & $9.85^{* *}$ \\
\hline Right & $11.09^{* *}$ & 2.38 & $4.29^{* *}$ & $3.65^{*}$ & 1.95 & 1.30 & 1.54 & $5.62^{*}$ & $44.63^{* * *}$ \\
\hline Purchase & $*$ & & & & & & & & \\
\hline Money & $6.01^{*}$ & $4.93^{* *}$ & $3.99^{* *}$ & .35 & 1.50 & .48 & .86 & $11.99^{* *}$ & $52.77^{* * *}$ \\
\hline Saving & & & & & & & & * & \\
\hline \multicolumn{10}{|c|}{ Multivariate Analysis of Variance } \\
\hline Wilks's Lambda & $4.34^{* *}$ & $5.28^{* * *}$ & $2.69^{* *}$ & $4.00^{* * *}$ & 1.30 & .67 & 1.32 & $8.74^{* * *}$ & $38.52^{* * *}$ \\
\hline
\end{tabular}

Note. ${ }^{*} p<.05,{ }^{* *} p<.01,{ }^{* * *} p<.001$.

Because the overall multivariate result was significant, the respective effect of an individual dependent variable was examined in a univariate analysis. When there were significant results in the univariate analyses, post-hoc multiple comparisons were conducted using the Bonferroni test. A descriptive summary is reported in Table 4 . The findings are discussed by main effects and interaction effects. 
Table 4. Summary of findings

\begin{tabular}{llll}
\hline $\begin{array}{l}\text { Main Effects } \\
\text { Effort/Time Saving }\end{array}$ & Product Type & Gender & Generation \\
$\begin{array}{l}\text { Right Purchase } \\
\text { Money Saving }\end{array}$ & Clothing $>$ Grocery, Electronics & $\begin{array}{l}\text { Females }>\text { Males } \\
\text { Females }>\text { Males }\end{array}$ & $\begin{array}{l}\text { Seniors }>\text { Gen Y } \\
\text { Baby Boomers, Seniors }>\text { Gen Y }\end{array}$ \\
\hline $\begin{array}{l}\text { Interaction Effects } \\
\text { Effort/Time Saving }\end{array}$ & $\begin{array}{l}\text { Product Type } \\
\text { Grocery: Females }>\text { Males }\end{array}$ & & Gender \\
Right Purchase & Grocery: Females $>$ Males & & Males: Clothing $>$ Electronics, Grocery \\
\hline
\end{tabular}

Note. *Planning as a control variable was significant at $p<.05$. For all other cells, both planning and search as control variables were significant at $p<.05$.

\subsection{Main Effects}

\subsubsection{Effort and Time Saving}

With effort and time saving as a dependent variable, the model was significant: $F(25,1471)=2.71, p<0.001$. The effect size was small $\left(\omega^{2}=0.03\right)$ (Keppel, 1991; Kirk, 1996). Specifically, there were no main effects of gender and product type, but there was a main effect of generation $(F=6.29, p<0.001)$. Planning, as a covariate, was also significant $(F=9.85, p<0.01)$. That is, after entering planning as a control effect, both Baby Boomers $(M=5.03)$ and Seniors $(M=5.19)$ reported greater levels of effort and time saving than Generation Y $(M=4.89)$ and Generation X $(M=4.92)$. In terms of interaction, only gender and product type was significant $(F=5.12, p<0.01)$.

\subsubsection{Right Purchase}

With right purchase as a dependent variable, the model was significant: $F(25,1471)=4.05, p<0.001$ and the effect size $\left(\omega^{2}=0.05\right)$ was close to medium $(=.06)$. Specifically, there were main effects of gender $(F=11.09, p<$ $0.01)$ and generation $(F=4.29, p<0.01)$. Planning, as a covariate, was significant $(F=44.63, p<0.001)$ as was searching $(F=5.62, p<0.05)$. With the same levels of planning and searching, female consumers $(M=5.29)$ were more likely to report their smart shopping experience resulted from right purchase than male consumers $(M=5.18)$; and Seniors $(M=5.37)$ reported right purchase as part of their smart shopping experience more strongly than Generation $\mathrm{Y}(M=5.13)$. In terms of interaction, only the interaction of gender and product type was significant $(F$ $=3.65, p<0.05$ ).

\subsubsection{Money Saving}

With money saving as a dependent variable, the model was significant: $F(25,1471)=7.47, p<0.001$ and the effect size was medium $\left(\omega^{2}=0.10\right)$. Specifically, there were main effects for all independent variables: gender $(F$ $=6.01, p<0.01)$, product type $(F=4.93, p<0.01)$, and generation $(F=3.99, p<0.05)$. Both covariates were significant: searching $(F=24.99, p<0.001)$ and planning $(F=109.98, p<0.001)$. After controlling the levels of searching and planning, clothing $(M=5.51)$ generated more money saving experience than grocery $(M=5.29)$ or electronics $(M=5.25)$; female consumers $(M=5.44)$ reported saving more money than male consumers $(M=5.31)$; and Baby Boomers $(M=5.40)$ and Seniors $(M=5.47)$ displayed more money saving experience than Generation $Y$ $(M=5.20)$. All interactions were insignificant.

\subsection{Interaction and Simple Main Effects}

Because there were significant interaction effects of gender and product type on "effort and time saving" and "right purchase," the slicing technique was employed to compare two genders separately for each product type and to compare the three product types separately for each gender (Figure 1). 


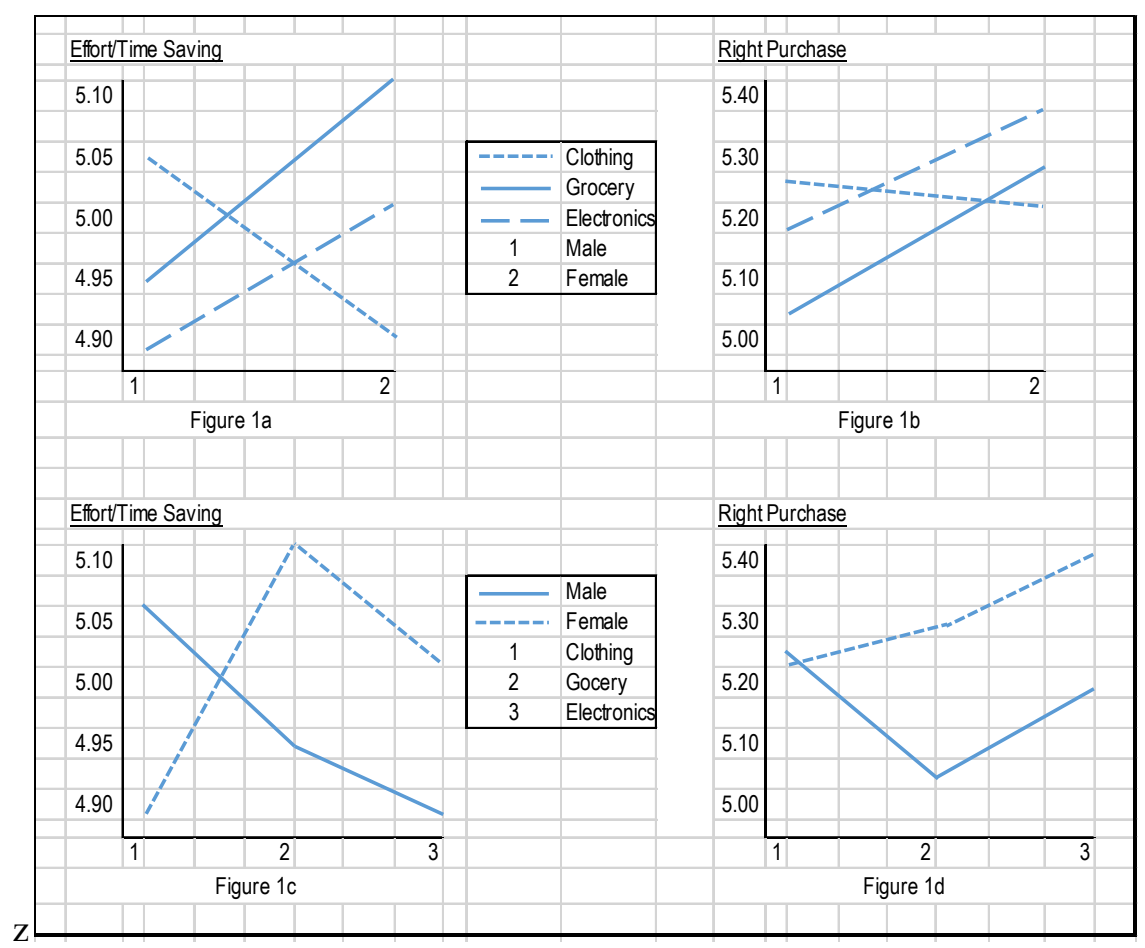

Figure 1. Interaction effects

\subsubsection{Simple Main Effect of Product Type}

Effort and time saving was compared between genders for each product type (Figure 1a). For clothing $(p=0.07)$ and electronics $(p=0.21)$, there were no differences. For grocery, there was a significant difference between genders $(p<0.01)$. For grocery, female consumers experienced greater effort and time saving $(M=5.30)$ than did male consumers $(M=5.10)$.

Right purchase was compared between genders for each product type (Figure 1b). For clothing $(p=0.92)$, there was no difference. For grocery $(p<0.001)$ and electronics $(p<0.05)$, there were significant differences. For grocery, females experienced making the right purchase $(M=5.36)$ more strongly than males $(M=5.28)$. For electronics, females experienced right purchase $(M=5.33)$ more strongly than males $(M=5.24)$.

\subsubsection{Simple Main Effect of Gender}

Effort and time saving was compared among three product types for each gender (Figure 1c). For male consumers, there was no difference among product types $(p=0.20)$. For female consumers, there was a significant difference among product types $(p<0.01)$. For grocery, female consumers were more likely to experience effort and time saving $(M=5.12)$ than for electronics $(M=5.03)$ or clothing $(M=4.92)$.

Right purchase was compared among three product types for each gender (Figure 1d). For male consumers, there was a significant difference among product types $(p<0.05)$. For female consumers, there was no significant difference among product types $(p=0.23)$. For clothing, male consumers experienced making the right purchase $(M=5.29)$, more strongly than they did for electronics $(M=5.19)$ or grocery $(M=5.08)$.

\section{Discussion}

This study examined the effects of product type, gender, and generation on smart shopping purchase factors by adjusting to the same level of pre-purchase activities (i.e., search and planning). This study provides evidence that members of different genders, generational cohorts, when purchasing different product types, demonstrate distinct smart shopping purchase experiences in terms of saving time/effort, saving money, and making the right purchase.

When the data were analyzed based on each of the main effects, consumers reported the greatest level of money savings for purchasing clothing compared to purchasing grocery or electronics; females reported greater levels of making the right purchase and money saving than males; and Baby Boomers and Seniors reported higher levels of 
effort/time saving (than Gen Y \& Gen X) and money saving (than Gen Y). Seniors reported a higher level of making the right purchase than Gen $Y$.

When the data were analyzed based on interaction effects, females reported a greater level of effort/time saving when purchasing grocery than when purchasing electronics or clothing, while males reported a greater level of making the right purchase when purchasing clothing than purchasing electronics or grocery. Females reported higher levels of effort/time savings and right purchase than males for purchasing grocery products. Females also reported higher levels of right purchase than males for purchasing electronics.

Overall, money saving was most important for purchasing clothing; females perceived greater smart shopper feelings than males; and older consumers (Baby Boomers \& Seniors) reported higher levels of smart shopping than younger consumers (Generation Y \& Generation X). Furthermore, it was found that planning and search, as part of pre-purchase activities, had a significant impact on smart shopping feelings because these variables were significant covariates in most analyses.

\section{Implications and Future Research}

Based on the findings of this study, the researchers make recommendations to marketers to target different genders and generations of smart shoppers in purchasing different types of products. First, clothing marketers should take into consideration the importance of money savings to smart shoppers; therefore, they must emphasize product prices using promotions, markdowns, or other means of communicating price savings. Second, to target female smart shoppers, marketers should offer not only the above-mentioned money savings techniques, but also a wide variety/assortment of products that can meet the individual consumers' needs for right product and quality. Third, to target older smart shoppers (Baby Boomers \& Seniors) marketers must understand the importance of saving time/effort and money to these consumers. Providing in-store directional signage, information kiosks or in-store product pickup will increase the convenience of the shopping experience. Large-scale retail stores prove hard to navigate for older consumers; therefore, offering frequently purchased products such as pharmacy and staple food items closer to the entrance will meet their need for effort/time savings. Providing promotional savings such as senior discounts and coupons will entice and satisfy the older consumers. Furthermore, when targeting Seniors, who value getting the right purchase, it is important to offer product assortments that meet their needs. For example, marketers cannot carry the same products for Gen Y \& Seniors because their needs are different. Clothing retailers targeting Seniors could provide clothing that is more loose and less form-fitting; electronics stores need technology products that are simple to understand and use; grocery stores should recognize that Seniors prepare food at home less often than other consumer groups; therefore, retailers could offer food that is partially or fully prepared to fit Seniors' lifestyle needs.

Specific implications can also be drawn from the significant interaction effects. For female smart shoppers, grocery retailers must provide convenient tools (e.g., shopping carts with store layout/maps, online ordering with in-store pick up) to save time/effort as female shoppers do much of the shopping for the household and are typically interested in saving time/effort. The study indicates that right purchase is important to male smart shoppers when buying clothing and to females when buying grocery and electronics. Clothing retailers marketing to male smart shoppers could offer advice/instruction on proper fit/sizing and employ well-trained associates who assist, validate, and confirm their clothing selections. This technique may not be necessary for female consumers who have more experience and confidence in purchasing clothing (Bakewell \& Mitchell, 2006; Witkowski, 1999). For female smart shoppers, right purchase is important for purchasing grocery and electronics. Electronic retailers can focus on aesthetically pleasing products (with color or design options) to meet the needs of the female shopper. Rather than using technical terms, electronics stores could focus on providing practical and user-friendly information on product features and benefits for female shoppers. As female shoppers take the primary role of shopping for the household, grocery retailers can offer wide product assortments and quality choices. For example, Kroger has a supermarket format that offers increased product selection (e.g., home fashion, bed and bath, home office) in the Marketplace stores, which assists in meeting female smart shoppers' assortment needs. Finally, search is an important covariate influencing the levels of smart purchasing experiences, which supports the finding of Atkins \& Kim (2016). As a result, marketers should provide well-designed websites with in-depth, accurate, and up-to-date information to assist smart shoppers prior to in-store purchasing.

This study has some limitations that can open new avenues for future studies. The smart purchasing factors employed in this study consist of only three factors: effort/time saving, right purchase, and money savings. Given that current consumers have multiple shopping value dimensions (Kim et al., 2014), further studies can explore additional smart purchasing factors, especially considering the small and medium effect sizes in the 
results. In addition, only one product type (clothing, grocery, or electronics) was used for shopping goods, convenience goods, and specialty goods, respectively. Future studies can identify other frequently purchased products for each category to further validate the findings of this study.

\section{Conclusion}

Smart shopping is not only money savings but also includes effort/time savings, and making the right purchase. This study has demonstrated that smart shopping experiences differ by product type (RQ1), gender (RQ2), and generation (RQ3), when the levels of search and planning are controlled. Therefore, retailers must tailor their strategies when targeting different genders and generations of smart shoppers; these strategies must also be tailored to the specific product type, whether it is clothing (shopping goods), grocery (convenience goods), or electronics (specialty goods).

\section{References}

Apeagyei, P. R. (2011). The impact of image on emerging consumers of fashion. International Journal of Management Cases, 13(4), 242-251. http://dx.doi.org/10.5848/APBJ.2011.00133

Atkins, K. G. (2008). The smart shopping construct: Scale development and validation (Doctoral dissertation). University of Tennessee. Knoxville, TN. Retrieved from http://etd.utk.edu/2008/December2008Dissertations/AtkinsKellyGreen.pdf

Atkins, K. G., \& Kim, Y-K. (2012). Smart shopping: conceptualization and measurement. International Journal of Retail \& Distribution Management, 40(5), 360-375. http://dx.doi.org/10.1108/09590551211222349

Atkins, K. G., \& Kim, Y-K. (2016). Smart apparel shopping: A multi-dimensional and gender-neutral measure. Clothing and Textiles Research Journal, 34(1), 3-19. http://dx.doi.org/10.1177/0887302X15602097

Bakewell, C., \& Mitchell, V.-W. (2004). Male consumer decision-making styles. International Review of Retail, Distribution \& Consumer Research, 14(2), 223-240. http://dx.doi.org/10.1080/0959396042000178205

Bakewell, C., \& Mitchell, V.-W. (2006). Male versus female consumer decision making styles. Journal of Business Research, 59(12), 1297-1300. http://dx.doi.org/10.1016/j.jbusres.2006.09.008

Brosdahl, D. J. C., \& Carpenter, J. M. (2011). Shopping orientations of US males: A generational cohort comparison. Journal of Retailing \& Consumer Services, 18(6), 548-554. http://dx.doi.org/10.1016/j.jretconser.2011.07.005

Brown, T. A. (2006). Confirmatory factor analysis for applied research. New York, NY: Guilford Press.

Brynjolfsson, E., Hu, Y. J., \& Rahman, M. S. (2013). Competing in the age of omnichannel retailing. MIT Sloan Management Review, 54(4), 23-29.

Bucklin, L. P. (1963). Retail strategy and the classification of consumer goods. Journal of Marketing, 27(1), 50-55. http://dx.doi.org/10.2307/1248582

Cardinali, M. G., \& Bellini, S. (2014). Interformat competition in the grocery retailing. Journal of Retailing and Consumer Services, 21(4), 438-448. http://dx.doi.org/10.1016/j.jretconser.2014.03.005

Cleveland, M., Babin, B. J., Laroche, M., Ward, P., \& Bergeron, J. (2003). Information search patterns for gift purchases: A cross-national examination of gender differences. Journal of Consumer Behaviour, 3(1), 20-47. http://dx.doi.org/10.1002/cb.120

Copeland, M. T. (1923). Relation of consumers' buying habits to marketing methods. Harvard Business Review, 1(3), 282-289.

Crutsinger, M. (2006, January 31). Personal savings rate turns negative. The San Diego Union-Tribune. Retrieved from http://wwwsignonsandiego.com/uniontrib/20060131/news_1n31savings.html

Dennis, C., \& McCall, A. (2005). The Savannah hypothesis of shopping. Business Strategy Review, 16(3), 12-16. http://dx.doi.org/10.1111/j.0955-6419.2005.00368.x

Garretson, J. A., \& Burton, S. (2003). Highly coupon and sale prone consumers: Benefits beyond price savings. Journal of Advertising Research, 43(2), 162-172. http://dx.doi.org/10.2501/JAR-43-2-162-172

Hair, J. F., Black, W. C., Babin, B. J., \& Anderson, R. E. (2009). Multivariate data analysis (7th ed.). New York, NY: Pearson Prentice Hall.

Hale, T. (2010). Mining the U.S. generation gaps. Retrieved from http://www.nielsen.com/us/en/newswire/2010/mining-the-u-s-generation-gaps.html 
Haytko, D. L., \& Baker, J. (2004). It's all at the mall: Exploring adolescent girl' experiences. Journal of Retailing, 80(1), 67. http://dx.doi.org/10.1016/j.jretai.2004.01.005

Holton, R. H. (1958). The distinction between convenience goods, shopping goods, and specialty goods. Journal of Marketing, 23(1), 53-56. http://dx.doi.org/10.2307/1248017

Hu, H., \& Jasper, C. R. (2004). Men and women: A comparison of shopping mall behavior. Journal of Shopping Center Research, 11(1), 113-131.

Keppel, G. (1991). Design and analysis: A researcher's handbook (3rd ed.). Englewood Cliffs, NJ: Prentice-Hall.

Keselman, H., Huberty, C., Lix, L., Olejnik, S., Cribbie, R., Donnahue, B., \& Levin, J. (1998). Statistical practices of educational researchers: An analysis of their ANOVA, MANOVA, and ANCOVA analyses. Review of Educational Research, 68(3), 350-386.http://dx.doi.org/10.3102/00346543068003350

Kim, Y.-K., Sullivan, P., \& Forney, J. C. (2007). Experiential retailing: Concepts and strategies that sell. New York, NY: Fairchild.

Kim, Y-K., Lee, M., \& Park, S. (2014). Shopping value orientation: Conceptualization and measurement. Journal of Business Research, 67, 2884-2890. http://dx.doi.org/10.1016/j.jbusres.2012.06.006

Kirk, R. E. (1996). Practical significance: A concept whose time has come. Educational and Psychological Measurement, 56, 746-759. http://dx.doi.org/10.1177/0013164496056005002

Laroche, M., Saad, G., Cleveland, M., \& Browne, E. (2000). Gender differences in information search strategies for a Christmas gift. The Journal of Consumer Marketing, 17(6), 500-524. http://dx.doi.org/10.1108/07363760010349920

Mano, H., \& Elliott, M. T. (1997). Smart shopping: The origins and consequences of price savings. Paper presented at the Advances in Consumer Research, Provo, UT.

Men buy, women shop: The sexes have different priorities when walking down the aisles. (2007, Nov 28). Retrieved

from http://knowledge.wharton.upenn.edu/article/men-buy-women-shop-the-sexes-have-different-priorities-when -walking-down-the-aisles/

Miller, S. J., \& Zikmund, W. G. (1975). A multivariate analysis of prepurchase deliberation and external search behavior. Advances in Consumer Research, 2(1), 187-196.

Murphy, P. E., \& Enis, B. M. (1986). Classifying products strategically. Journal of Marketing, 50(3), 24-42. http://dx.doi.org/10.2307/1251583

Mushkin, S. (2012). Trouble in aisle 5. Retrieved from http://www.jefferies.com/CMSFiles/Jefferies.com/files/PressReleases/2012/TroubleinAisle5_062712.pdf

Neff, J. (2011). Time to rethink your message: Now the cart belongs to Daddy. Advertising Age, 82(3), 1.

Norum, P. S. (2003). Examination of generational differences in household apparel expenditures. Family and Consumer Sciences Research Journal, 32(1), 52-75. http://dx.doi.org/10.1177/1077727X03255901

Parment, A. (2013). Generation Y vs. Baby Boomers: Shopping behavior, buyer involvement and implications for retailing. Journal of Retailing \& Consumer Services, 20(2), 189-199. http://dx.doi.org/10.1016/j.jretconser.2012.12.001

Reeves, T. C., \& Oh, E. J. (2007). Generation differences and educational technology research. In J. M. Spector, M. D. Merrill, J. J. G. van Merriënboer, \& M. Driscoll. (Eds.), Handbook of research on educational communications and technology (pp. 295-303). Mahwah, NJ: Lawrence Erlbaum Associates.

Schindler, R. M. (1998). Consequences of perceiving oneself as responsible for obtaining a discount: Evidence for smart-shopper feelings. Journal of Consumer Psychology, 7(4), 371-392. http://dx.doi.org/10.1207/s15327663jcp0704_04

Shimp, T. A., \& Kavas, A. (1984). The theory of reasoned action applied to coupon usage. Journal of Consumer Research, 11(3), 795-809.http://dx.doi.org/10.1086/209015

Slama, M. E., \& Tashchian, A. (1985). Selected socioeconomic and demographic characteristics associated with purchasing involvement. Journal of Marketing, 49(1), 72-82. http://dx.doi.org/10.2307/1251177 
The future of retail. (2013). Stores Top 250. Retrieved from http://www.stores.org/STORES\%20Magazine\%20January\%202013/future-retail

Urbany, J. E., Dickson, P. A., \& Kalapurakal, R. (1996). Price search in the retail grocery market. Journal of Marketing, 60(2), 91-104. http://dx.doi.org/10.2307/1251933

Van Slyke, C., Comunale, C. L., \& Belanger, F. (2002). Gender differences in perceptions of web-based shopping. Communications of the ACM, 45(8), 82-86. http://dx.doi.org/10.1145/545151.545155

Wallner, A., \& Matisic, K. (2005). The shopping bag: Tips, tricks and information to make you a savvy shopper. New York: Dutton.

Warne, R. (2014). A primer on multivariate analysis of variance (MANOVA) for behavioral scientists. Practical Assessment, Research and Evaluation, 19(17), 1-10. Retrieved from $\mathrm{http}: / /$ pareonline.net/getvn.asp? $\mathrm{v}=19 \& \mathrm{n}=17$

Wiedmann, K.-P., Walsh, G., \& Mitchell, V.-W. (2001). The mannmaven: an agent for diffusing market $\begin{array}{llll}\text { information. Journal of Marketing } & \text { Communications, } & \text { 7(4), }\end{array}$ 195-212.http://dx.doi.org/10.1080/13527260127413

Witkowski, T. (1999). The early development of purchasing roles in the American household. Journal of Macromarketing, 19(2), 104-114. http://dx.doi.org/10.1177/0276146799192002

Worsley, T., Wang, W. C., \& Hunter, W. (2011). Baby boomers' reasons for choosing specific food shops. International Journal of Retail \& Distribution Management, 39(11), 867-882. http://dx.doi.org/10.1108/09590551111177972

Young, V. M. (2011). Fairchild's fashion group mens wear industry CEO summit. Women's Wear Daily, p. 1.

\section{Copyrights}

Copyright for this article is retained by the author, with first publication rights granted to the journal.

This is an open-access article distributed under the terms and conditions of the Creative Commons Attribution license (http://creativecommons.org/licenses/by/3.0/) 